\title{
PENGARUH SHOPPING EXPERIENCE TERHADAP BRAND IAMGE KAWASAN OBJEK WISATA BELANJA BATIK TRUSMI \\ (Survei terhadap Pengunjung Kawasan Objek Wisata Belanja Batik Trusmi Kabupaten Cirebon)
}

\author{
Ranny Achni Novianti \\ Ridwan Purnama \\ Manajemen Pemasaran Pariwisata FPIPS UPI
}

\begin{abstract}
Kabupaten Cirebon is one of regencies in West java has tourism potential can be relied, and the one of destination is Kawasan Objek Wisata Belanja Batik Trusmi. Kawasan Objek Wisata Belanja Batik Trusmi is a shopping tourism area that offers a variety oftypicalCirebonanbatikcollection. The number of tourist visits on Kawasan Objek Wisata Belanja Batik Trusmi has decreased from 2007 to 2010. The most drastic decrease of tourist visit happened in 2010. Shopping experience is one of marketing strategy that can be used to increase the number of visit. In connection with these to research studies conducted on the influence shopping experience toward brand image Kawasan Objek Wisata Belanja Batik Trusmi. The purpose of this research is to find shopping experience influence brand image to Kawasan Objek Wisata belanja Batik Trusmi. Promotion mix consists of price, characteristics ofdestinations, merchandising, authenticity, and staff service quality. Technique of sampling is simple random sampling. The method in that used in this research is explanatory survey by using ordinal scale.Analyze from this research use Path Analysis with a computer software tools SPSS 19.0. The result of this research is shopping experience influence significantly 71,48\% and the rest influence other factors. Based on the result of statistical test results were obtained, there were three variables of shopping experience which had an influence on brand image of price, merchandising, and authenticity and there was two variables that had no effect on brand image was characteristics ofdestinations and staff service quality. That it can be concluded that price, merchandising, and authenticity strong influence brand image on Kawasan Objek Wisata Belanja Batik Trusmi.
\end{abstract}

Key word: Shopping Experience, Brand Image

\section{PENDAHULUAN}

\subsection{Latar Belakang}

Pariwisata adalah salah satu jenis industri yang mampu mempercepat pertumbuhan ekonomi dan penyediaan lapangan kerja, peningkatan penghasilan, standar hidup serta menstimulasi sektorsektor produktif lainnya. Selanjutnya, sebagai sektor yang kompleks, pariwisata juga merealisasi industri-industri klasik seperti industri kerajinan tangan dan cinderamata, penginapan serta transportasi.

UNWTO memprediksi bahwa pada tahun 2020 pariwisata akan menajdi industry terbesar di dunia dengan perkiraan 1.602 miliyar wisatawan interasional, dan merupakan penggerak pertumbuhan ekonomi dan kesempatan kerja yang mampu menciptakan pendapatan dunia sebesar USD 2 triliun. Indonesia merupakan negara dengan urutan ke delapan yang dikunjungi oleh 5,064 juta wisatawan (http://kolom.pacific.net.id, 5 April 2010).

Kepariwisataan di Indonesia pun saat ini memberikan dorongan dan sumbangan terhadap perkembangan perekonomian.Jawa Barat merupakan salah satu provinsi di Indonesia yang memiliki potensi pariwisata yang cukup baik.Jawa Barat mempunyai kota atau wilayah yang sangat potensial untuk dijadikan sebagai daerah tujuan wisata yang dapat menghasilkan pendapatan bagi warga setempat serta mendatangkan devisa untuk negara karena memiliki kekayaan dan keragaman sumber daya pariwisata yang tinggi, meliputi: wisata alam, wisata budaya, dan wisata minat khusus.

Kabupaten Cirebon merupakan salah satu kabupaten yang berada di Provinsi Jawa Barat.Kabupaten Cirebon memiliki objek wisata ziarah, objek wisata alam dan objek wisata belanja. Salah satu objek wisata belanja andalan dan satu-satunya di Kabupaten Cirebon ini adalah Kawasan Objek Wisata Belanja Batik Trusmi. Kawasan Objek Wisata Belanja Batik Trusmi merupakan kawasan objek wisata belanja batik yang menawarkan batik tulis, batik cap dan batik kombinasi tulis cap dengan berbagai corak dan motif khas Cirebonan. 
Lokasi Kawasan Objek Wisata Belanja Batik ini berada di tempat yang strategis karena letaknya tidak jauh dari pusat Kota Cirebon. Selain itu, pembangunan Tol Kanci Pejagan juga memiliki dampak yang cukup besar bagi Kawasan Objek Wisata Belanja Batik Trusmi. Umumnya wisatawan yang datang berasal dari daerah sekitar Kabupaten Cirebon dan Jawa Tengah. Akibatnya dari dibukanya jalan Tol Kanci Pejagan, wisatawan yang berasal dari Jawa Tengah banyak mengunjungi Kabupaten Cirebon. Beriku adalah data statistik mengenai jumlah kunjungan wisatawan nusantara ke Kawasan Objek Wisata Belanja Batik Trusmi tahun 2007-2010:

TABEL 1

DATA KUNJUNGAN WISATAWAN

NUSANTARA KE KAWASAN WISATA BELANJA BATIK TRUSMI TAHUN 2007-2010

\begin{tabular}{ccc}
\hline No. & Tahun & $\begin{array}{c}\text { Jumlah } \\
\text { Wisatawan }\end{array}$ \\
\hline $\mathbf{1}$ & 2007 & 431.099 \\
$\mathbf{2}$ & 2008 & 270.080 \\
$\mathbf{3}$ & 2009 & 465.955 \\
$\mathbf{4}$ & 2010 & 224.267 \\
\hline
\end{tabular}

Sumber:Disbudparpora Kabupaten Cirebon, 2011

Jumlah wisatawan yang berkunjung ke Kawasan Objek Wisata Belanja Batik Trusmi tahun 2007-2010 mengalami penurunan. Penurunan jumlah yang signifikan terjadi pada tahun 2010 yaitu sebanyak 241.688 orang.

Untuk meningkatkan jumlah kunjungan maka Disbudparpora kabupaten Cirebon melaksanakan strategi shopping experience yang terdiri dari harga, karakteristik destinasi, merchandising, keaslian dan staff service quality. Dengan strategi shopping experience yang dilakukan oleh Kawasan Objek Wisata Belanja Batik Trusmi dapat menjadi suatu pengaruh kepada wisatawan untuk datang berkunjung dan memberikan image yang baik terhadap kawasan Trusmi ini.

Berdasarkan latar belakang di atas, maka perlu diadakan penelitian dengan judul "Pengaruh Shopping Experience terhadap Brand Image Kawasan Objek Wisata Belanja Batik Trusmi (Survei terhadap Pengunjung Kawasan Objek Wisata Belanja Batik Trusmi.

\subsection{Rumusan Masalah}

Berdasarkan uraian latar belakang yang telah dikemukakan di atas, maka rumusan masalah dalam penelitian ini adalah sebagai berikut:

4. Bagaimana shopping experience di kawasan objek wisata belanja Batik Trusmi.

5. Bagaimana brand image di kawasan objek wisata belanja Batik Trusmi.

6. Seberapa besar pengaruh shopping experience terhadap brand image di Kawasan Objek Wisata Belanja Batik Trusmi baik secara simultan maupun parsial.

\subsection{Tujuan Penelitian}

Berdasarkan dari rumusan masalah yang telah dikemukakan di atas, maka tujuan dalam penelitian ini untuk memperoleh temuan mengenai:

4. Shopping experience di kawasan objek wisata belanja Batik Trusmi terdiri dari harga, karakteristik destinasi, merchandising, keaslian dan staff service quality.

5. Brand image di kawasan objek wisata belanja Batik Trusmi.

6. Pengaruh shopping experience terhadap brand image di kawasan objek wisata belanja Batik Trusmi baik secara simultan atau parsial.

\subsection{Kegunaan Penelitian}

adalah:

Adapun kegunaan dari penelitian ini

1. Secara teoritis hasil penelitian ini diharapkan dapat memperluas kajian ilmu manajemen pariwisata khususnya mengenai shopping experience khususnyaharga, karakteristik destinasi, merchandising, keaslian dan staff service quality yang dilakukan untuk menciptakan brand image di kawasan objek wisata belanja Batik Trusmi serta diharapkan penelitian ini dapat memperluas mengenai ilmu pemasaran pariwisata.

2. Secara praktis hasil penelitian ini diharapkan dapat memberikan masukan bagi pihak-pihak dalam bidang pariwisata Kabupaten Cirebon, khususnya bagi kawasan objek wisata belanja Batik Trusmi dalam upaya menarik para wisatawan untuk menciptakan brand image ke Kabupaten Cirebon melalui kegiatan shopping experience. Diharapkan hasil penelitian ini dapat dijadikan masukan bagi pihakpihak dalam bidang pariwisata dalam upaya meningkatkan dan 
mempertahankan jumlah kunjungan ke Kabupaten Cirebon.

\section{KAJIAN PUSTAKA}

\subsection{Kerangka Pemikiran}

Asosiasi Pemasaran Amerika, menyatakan bahwa pemasaran adalah satu fungsi organisasi dan seperangkat proses untuk menciptakan, mengkomunikasikan dan menyerahkan nilai kepada pelanggan dan mengelola hubungan pelanggan dengan cara yang menguntungkan organisasi dan para pemilik sahamnya.

Jasa mempunyai karakteristik utama, menurut Kotler \& Keller (2009:389), Kotler, Bowen \& Maken (2006:42) karakteristik jasa dalam hospitality and tourism marketing yaitu (1) intangible, (2) inseparability, (3) variability, (4) perishability dan (5) lack of ownership.

Konsep pemasaran adalah filosofi bisnis yang lebih baru dan marak digunakan dalam industri pariwisata. Menurut Kotler, Bowen \& Maken dalam marketing for hospitality and tourism (2009:18) menyatakan bahwa "Pencapaian tujuan organisasi dalam industri periwisata tergantung pada penentuan kebutuhan dan keinginan pasar sasaran dan memberikan kepuasan yang diinginkan secara lebih efektif dan efisien pada konsumen dari pada pesaing lainnya."

Destination marketing merupakan bagian integral dari pengembangan dan mempertahankan popularitas lokasi tertentu. Perencanaan pariwisata tidak hanya fokus terhadap pengembangan destinasi, tetapi juga harus memperhatikan bahkan mempertahankan dan melestarikan atribut yang menarik wisatawan untuk tetap datang berkunjung.

Klasifikasi atraksi wisata menurut Kotler, Bowen \& Maken (2009:506) dibagi menjadi 7, yaitu (1) Medical Tourism Attraction, (2) Historic Tourism Attraction,

(3) Culinary Tourism Attraction, (4) Agritourism Attraction, (5) Shopping tourism Attraction, (6) Volunteer Vacationing, (7) Religious Pilgrimages.

Menurut Pitana dan Diarta (2009:76) menyatakan bahwa salah satu wisata yang termasuk dalam sumber daya minat khusus adalah shopping tourism. Menurut Timothy (2007) mengemukakan bahwa, "shopping is a social phenomenon and involves much more than simply the acquisition of product". Artinya, belanja adalah sebuah fenomena sosial dan melibatkan lebih banyak kegiatan dari akuisisi produk yang sederhana.

Menurut Timothy (2007) dalam jurnal Tourist Shopping experience and Satisfaction mengatakan bahwa, "shopping as a major leisure activity has become an important element in tourism". artinya, belanja merupakan aktivitas utama leisure yang menjadi elemen penting dalam wisata.

Menurut Timothy (2005:43), terdapat tiga faktor utama pendorong yang paling berperan penting yang merupakan faktor utama dalam wisata diantaranya (1) The Merchandise, (2) The Destination, (3) Price Advantages.

Berbelanja atau lazim pula dikatakan shopping sebagai kegiatan rekreasi besar telah menjadi elemen penting dalam pariwisata. Menurut Timothy (2007) mengemukakan bahwa, "shopping is a social phenomenon and involves much more than simply the acquisition of products. As a result, salespeople play an important role in creating the shopping experience". Artinya, belanja merupakan fenomena sosial dan melibatkan lebih dari sekedar akuisisi produk. Akibatnya, penjual bermain peran penting dalam menciptakanbelanjapengalaman.

Shopping tourism termasuk salah satu faktor yang memotivasi wisatawan untuk melakukan perjalanan. Menurut Timothy (2005:42), shopping tourism adalah belanjasebagaiatraksi

tambahanpadatujuanyang dikunjungi wisatawan

untukmayoritaspengeluaranwisatawanatauba rang-barangritel di sebuah toko. Menurut Drinea dan Gina (2009) mengemukakan bahwa konsep shopping tourism adalah adanya pembelian yang baik merupakan bagian dari waktu berwisata, waktum luang selama berwisata yang tujuannya telah diketahui sebelumnya oleh wisatawan.

Pengalaman menurut Timothy (2007:88) adalah suatu kombinasi yang lengkap dari faktor bentuk perasaan wisatawan dan sikap wisatawan ketika berkunjung dan menghabiskan waktu di daerah tujuan wisata. Berdasarkan jurnal dari Darren J. Timothy (2007), shopping tourism terdiri dari (1) shopping experience dan (2) shopping satisfaction.

Shopping experience tidak hanya didapatkan dari pengalaman internal yaitu self experience atau diri sendiri, tetapi juga didapatkan dari pengalaman external yaitu out-self experience atau wisatawan lain yang 
pernah mengunjungi suatu daerah tujuan wisatawan dengan rekomendasi melalui word of mouth.

Menurut Timothy (2007:88), mengemukakan bahwa "shopping is on of the oldest activities associated with, and one of the most common undertakings during, travel. For most tourist, in fact, a vacation experience would be incomplete without opportunities to shop."

Menurut Timothy (2007:88), menyatakan bahwa "shopping experience is shopping refers to a contemporary recreational activity involving looking, touching, browsing and buying, which helps fulfil people's need for enjoyment and relaxation and which helps tourist escape from their daily routines."

Shopping experience adalah aktivitas berbelanja yang mengacu kepada aktivitas rekreasi kontemporer yang melibatkan wisatawan untuk melihat, menyentuh, mencari dan membeli, yang mana membantu memenuhi kebutuhan wisatawan untuk menikmati dan mereksasikan dengan membantu wisatawan melarikan diri dari aktivitas sehari-harinya. Penilaian mengenai shopping experience diciptakan oleh kegiatan pemasaran yang menyangkut harga, karakteristik destinasi, merchandising, keaslian dan karakter penjual menurut wisatawan. Dimensi dari shopping experience Timothy (2007:88), diantaranya (1) Harga, (2) Karakteristik Destinasi, (3) Merchandising, (4) Keaslian, (5) Staff Service Quality.

Menurut Timothy (2007), dapat disimpulkan bahwa pengelola suatu objek daerah tujuan wisata belanja harus berusaha memberikan image yang baik terhadap wisatawan karena pengalaman berbelanja atau shopping experience merupakan salah satu alat untuk membangun image daerah tujuan wisata dengan baik". Inidapat menunjukkanbahwaseorang turisyang dikelola dengan baikpengalaman belanja yangdapat

berfungsisebagaialatuntukmembanguncitray ang lebih menguntungkan dariwisatatujuan.Menurut Timothy (2007) mengemukakan bahwa " produk yang dibeli oleh para wisatawan untuk alasan yang berbeda dapat membantu tujuan mengembangkan citra yang baik dipikiran wisatawan dan teman-teman atau kerabat, karena orang-orang pada umumnya, dan wisatawan khususnya, cenderung berbagi pengalaman mereka melalui foto, video, dan barang-barang mereka membeli ketika melakukan shopping trips."

Berdasarkan yang telah dikemukakan Timothy di atas, maka dapat menunjukkan bahwa seorang turis yang dikelola dengan baik pengalaman belanja yang dapat berfungsi sebagai alat untuk membangun citra yang lebih menguntungkan dari daerah tujuan wisata. Menurut Timothy (2007) menyiratkan bahwa pemahaman tentang motivasi wisatawan mengunjungi tujuan wisata, sangat penting bagi pemasar untuk mengembangkan citra yang lebih baik untuk tujuan dan produk yang mereka mempromosikan, dan menilai kualitas layanan mereka. Jadi, dari adanya holistik sudut pandang, menggunakan setiap elemen dari produk pariwisata memberikan kontribusi untuk keseluruhan pengalaman perjalanan yang sangat penting untuk menetapkan tujuan yang lebih baik.

Pariwisata sebagai industri yang makin berkembang merupakan suatu proses yang dapat menciptakan nilai tambah terhadap barang dan jasa baik yang nyata (tangible product) maupun yang tidak nyata (intangible product). Merek adalah produk yang memiliki sifat intangible, merek tidak dapat dilihat namun dapat diukur dan dapat dilihat image dari merek tersebut.

Image dapat diukur melalui pendapat, kesan tanggapan seseorang dengan tujuan untuk mengetahui secara pasti apa yang ada dalam pikiran setiap individu mengenai suatu objek, bagaimana mereka memahami dan apa yang disukai dari objek tersebut. Citra suatu objek tergantung persepsi yang diambil oleh seseorang yang mungkin persepsi sama dimiliki setiap orang.

Brand image pada dasarnya adalah hasil pandang konsumen terhadap suatu merek tertentu, yang didasarkan atas pertimbangan dan perbandingan dengan beberapa merek lainnya. Suatu merek yang telah mapan akan memiliki posisi yang kuat dalam persaingan bila didukung oleh asosiasi yang kuat. Berbagai asosiasi merek yang saling berhubungan akan menimbulkan suatu rangkaian yang disebut brand image.

Brand image yang diteliti diadaptasi dari teori brand image city, karena brand image dapat menjadi dasar untuk mengukur brand image city. Pada prinsipnya penelitian ini dilakukan untuk melihat brand image suatu objek yaitu kawasan objek wisata belanja Batik Trusmi. Menurut Jansson dan Dominic (2006:7) dan Wanijiru (2005:85) bahwa stength, favourability dan uniquenes 
adalah kunci dari sebuah brand image. Brand image Destinasiadalah alat untuk memperkuat identitas lokal suatu destinasi, dan sebagai salah satu ajang untuk memperlihatkan atau mengidentifikasi ciri khas yang terdapatdalam destinasi tersebut.

Sebuah brand image yang positif diciptakan oleh program pemasaran yang memiliki strength (kekuatan), favourable (Keuntungan), dan uniqueness (Keunikan), terhadap merek didalam ingatan. Berikut merupakan dimensi dari brand image menurut Jansson dan Dominic (2006).

1. Strength merupakan suatu fungsi dari jumlah atau kualitas, dari pengolahan informasi, dari pengolahan informasi seperti halnya dalam menerima kealamian mutu, dalam pengolahan itu. Semakin seseorang memikirkan informasi produk dan menghubungkannya dengan pengetahuan merek yang ada, maka yang lebih kuat dapat menghasilkan asosiasi merek.

2. Favourability adalah memilih asosiasi yang unik dan menguntungkan untuk menghubungkan kepada merek memerlukan analisa yang seksama dari konsumen dan kompetisi untuk menentukan yang optimal dalam memposisikan merek. Pengertian yang paling dasar, asosiasi merek yang baik diciptakan dengan meyakinkan konsumen bahwa merek memiliki kesesuaian atribut dan cukup meyakinkan bermanfaat.

3. Uniqueness merupakan Merek mempunyai suatu keuntungan yang kompetitif atau rancangan penjualan yang unik dan itu meberikan konsumen suatu alasan mengapa mereka perlu membeli merek tertentu.

Berdasarkan kerangka pemikiran diatas dapat disimpulkan bahwa dengan adanya shopping experience maka dapat dijadikan sebagai upaya dalam membentuk dan membangun brand image dari sebuah kawasan objek wisata atau destinasi wisata. Berikut akan disajikan gambar kerangka pemikiran mengenai pengaruh shopping experience terhadap brand image pada Gambar 1 berikut. 


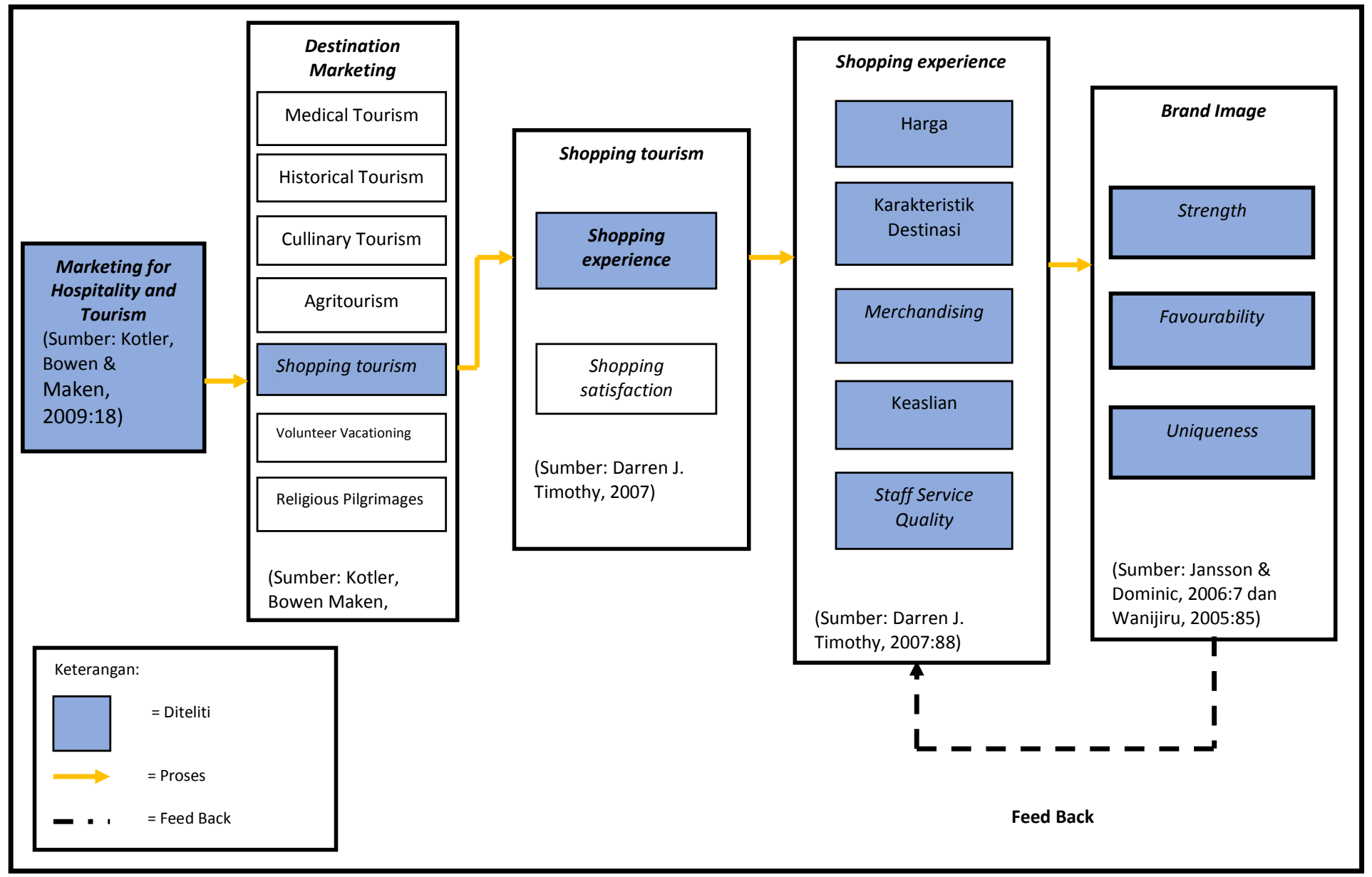

GAMBAR 1

KERANGKA PEMIKIRAN PENGARUH SHOPPING EXPERIENCE TERHADAP BRAND IMAGE KAWASAN OBJEK WISATA BELANJA BATIK TRUSMI 


\subsection{Hipotesis Penelitian}

Hipotesis merupakan jawaban sementara terhadap masalah penelitian yang dibangun berdasarkan kerangka pemikiran tertentu yang kebenarannya perlu diuji secara empiris. Terdapat premis-premis pendukung dari penelitian ini, sebagai berikut:

1. Tosun dan Fyall (2007)

Suatu objek daerah tujuan wisata belanja harus mampu memberikan image yang baik terhadap wisatawan karena pengalaman berbelanja atau shopping experience merupakan salah satu alat untuk membangun image daerah tujuan wisata dengan baik.

2. Darren J. Timothy (2005)

Setiap elemen dari produk wisata memberikan kontribusi seluruhnya terhadap pengalaman wisata yang sangat penting untuk membangun image destinasi yang lebih baik dan mempunyai perbedaan dengan destinasi lain di seluruh dunia.

3. Kim dan Littrell (2007)

Produkyang dibelioleh para wisatawan untuk alasan yang berbeda dapat membantu tujuan mengembangkan citra destinasi yang baik di pikiran wisatawan dan teman-teman atau kerabat, karena orang-orang pada umumnya, dan wisatawan khususnya, cenderung berbagi pengalaman mereka melalui foto, video, dan barang-barang mereka membeli ketika melakukan shopping trips.

Berdasarkan beberapa teori yang telah dijelaskan dan berdasarkan paradigma penelitian yang telah dianut di atas, maka penulis merumuskan hipotesis untuk penelitian ini yaitu terdapat pengaruh secara signifikan antara shopping experience terhadap brand image baik secara simultan maupun parsial.

\section{METODE PENELITIAN}

\subsection{Objek Penelitian}

Penelitian ini menganalisis mengenai pengaruh shopping experience terhadap brand image kawasan objek wisata belanja Batik Trusmi. Selanjutnya penelitian ini akan meneliti dua variabel inti, yaitu variabel bebas dan variabel terikat.

Variabel bebas (independent variable) yang diteliti yaitu shopping experience (X) yang meliputi harga $\left(\mathrm{X}_{1}\right)$, karakteristik destinasi $\left(\mathrm{X}_{2}\right)$, merchandising $\left(\mathrm{X}_{3}\right)$, keaslian $\left(\mathrm{X}_{4}\right)$ dan staff service quality $\left(\mathrm{X}_{5}\right)$. Variabel terikat (dependent variable) yang diteliti adalah brand image (Y) yang meliputi strength, favourability dan uniquenes. Responden yang menjadi unit analisis dari penelitian ini adalah pengunjung kawasan objek wisata belanja Batik Trusmi.

\subsection{Metode Penelitian}

\subsubsection{Jenis Penelitian dan Metode yang Digunakan}

Berdasarkan variabel-variabel yang diteliti maka jenis penelitian dari penelitian ini adalah penelitian deskriptif dan verifikatif. Sugiyono (2008:35) mendefinisikan bahwa penelitian deskriptif adalah penelitian yang dilakukan untuk mengetahui nilai variabel mandiri, baik satu variabel atau lebih tanpa membuat perbandingan atau menghubungkan dengan variabel lain. Tujuan metode deskriptif menurut Mely dalam Ulber Silalahi (2009:27) adalah menggambarkan secara tepat sifat-sifat suatu individu, keadaan, gejala, atau kelompok tertentu, atau untuk menentukan frekuensi atau penyebaran suatu gejala atau frekuensi adanya hubungan tertentu antara suatu gejala dan gejala lain. Penelitian deskriptif disini bertujuan untuk memperoleh deskripsi atau gambaran mengenai shopping experience $(\mathrm{X})$ yang memiliki lima sub variabel yaitu harga $\left(\mathrm{X}_{1}\right)$, karakteristik destinasi $\left(\mathrm{X}_{2}\right)$, merchandising $\left(\mathrm{X}_{3}\right)$, keaslian $\left(\mathrm{X}_{4}\right)$ dan staff service quality $\left(\mathrm{X}_{5}\right)$. Kemudian objek penelitian yang menjadi variabel terikat (dependentvariable) adalah brand image $(\mathrm{Y})$ sebagai variabel terikat yang memiliki dimensiyang terdiri dari strength, favourabiity dan uniqueness.

Penelitian verifikatif merupakan penelitian yang bertujuan untuk mengetahui pengaruh antara dua variabel atau lebih. Dengan penelitian verifikatif maka akan dapat dibangun suatu teori yang dapat berfungsi untuk menjelaskan, meramalkan, dan mengontrol suatu gejala (Sugiyono, 2008:11). Selanjutnya menurut Suharsimi Arikunto (2009:8) memaparkan bahwa sifat penelitian verifikatif pada dasarnya ingin menguji kebenaran dari suatu hipotesis penelitian yang dilakukan melalui pengumpulan data di lapangan, dalam penelitian ini di uji pengaruh shopping experience terhadap brand image kawasan objek wisata belanja Batik Trusmi.

Berdasarkan jenis penelitian deskriptif, metode penelitian yang digunakan adalah metode deskriptif survey dan metode explanatory survey untuk menjelaskan 
hubungan antara variabel-variabel melalui pengujian hipotesis. Metode tersebut dipergunakan untuk menjelaskan hubungan antara variabel-variabel penelitian melalui pengujian hipotesis. Menurut Sugiyono (2008:11) yang dimaksud dengan metode survei yaitu " Metode survei digunakan untuk mendapatkan data dari tempat tertentu yang alamiah (bukan buatan), tetapi peneliti melakukan perlakuan dalam pengumpulan data, misalnya dengan mengedarkan kuesioner, test, wawancara terstruktur dan sebagainya (perlakuan tidak seperti dalam eksperimen)."

Penelitian yang menggunakan metode ini, melakukan kegiatan pengumpulan informasi dari sebagian populasi secara langsung di tempat kejadian (empirik) dengan tujuan untuk mengetahui pendapat dari sebagian populasi terhadap objek yang sedang diteliti.

Metode pengembangan yang dipergunakan adalah cross sectional method. Menurut Husein Umar (2009:42), cross sectional method yaitu metode penelitian dengan cara mempelajari objek, dalam kurun waktu tertentu tidak berkesinambungan dalam jangka waktu panjang. Pada penelitian dengan pembelian metode ini, informasi dari sebagian populasi dikumpulkan langsung ditempat kejadian secara empirik dengan tujuan untuk mengetahui pendapat dari sebagian populasi terhadap objek yang sedang diteliti.

\subsubsection{Operasionalisasi Variabel}

Penelitian ini meliputi dua variabel, yaitu variabel bebas dan variabel terikat. Variabel bebas (X) yang diteliti dalam penelitian ini adalah shopping experience dengan yang memiliki lima sub variabel yang terdiri dari harga $\left(\mathrm{X}_{1}\right)$, karakteristik destinasi $\left(\mathrm{X}_{2}\right)$, merchandising $\left(\mathrm{X}_{3}\right)$, keaslian $\left(\mathrm{X}_{4}\right)$ dan staff service quality $\left(\mathrm{X}_{5}\right)$. Kemudian objek penelitian yang menjadi variabel terikat (Y) yang diteliti adalah brand imageyang memiliki dimensi yang terdiri dari strength, favourability dan uniquenes.

Pengoperasian variabel dari kedua variabel yang dijadikan objek pada penelitian ini menggunakan skala ordinal. Operasionalisasi variabel penelitian disajikan pada Tabel 2.

TABEL 2

OPERASIONALISASI VARIABEL PENELITIAN

\begin{tabular}{|c|c|c|c|c|}
\hline $\begin{array}{c}\text { Variabel/ Sub } \\
\text { Variabel }\end{array}$ & Konsep Variabel & Indikator & Ukuran & Skala \\
\hline 1 & 2 & 3 & 4 & 5 \\
\hline $\begin{array}{l}\text { Shopping } \\
\text { Experience (X) }\end{array}$ & $\begin{array}{l}\text { Pengalaman berbelanja adalah } \\
\text { kegiatan belanja yang merupakan } \\
\text { aktivitas kontemporer rekreasi yang } \\
\text { didalamnya termasuk melihat, } \\
\text { menyentuh, mencari dan membeli, } \\
\text { dimana orang-orang atau wisatawan } \\
\text { untuk merasa nyaman dan santai serta } \\
\text { membantu wisatawan untuk sejenak } \\
\text { melupakan aktivitas sehari-hari. } \\
\text { (Darren J. Timothy, 2007:88) }\end{array}$ & & & \\
\hline \multirow[t]{3}{*}{ Harga (X.1) } & & $\begin{array}{l}\text { Daya tarik harga } \\
\text { yang ditawarkan }\end{array}$ & $\begin{array}{l}\text { Daya tarik harga } \\
\text { yang ditawarkan }\end{array}$ & Ordinal \\
\hline & & $\begin{array}{ll}\text { Kesesuaian } \\
\text { harga yang } \\
\text { ditawarkan } \\
\text { dengan produk }\end{array}$ & $\begin{array}{ll}\text { - } & \text { Tingkat } \\
\text { kesesuaian harga } \\
\text { yang ditawarkan } \\
\text { dengan produk }\end{array}$ & Ordinal \\
\hline & & $\begin{array}{l}\text { Keragaman } \\
\text { harga yang } \\
\text { ditawarkan }\end{array}$ & $\begin{array}{ll}\text { - } & \text { Tingkat } \\
\text { keragaman harga } \\
\text { yang ditawarkan }\end{array}$ & Ordinal \\
\hline \multirow[t]{2}{*}{$\begin{array}{c}\text { Karakteristik } \\
\text { Destinasi (X.2) }\end{array}$} & & $\begin{array}{ll} & \text { Kenyamanan } \\
\text { showroom atau } \\
\text { toko }\end{array}$ & $\begin{array}{ll}\text { Tingkat } \\
\text { kenyamanan } \\
\text { showroom atau } \\
\text { toko } \\
\end{array}$ & Ordinal \\
\hline & & $\begin{array}{ll} & \text { Kepopuleran } \\
\text { objek wisata } \\
\text { dengan batiknya }\end{array}$ & $\begin{array}{ll}- & \text { Tingkat } \\
\text { kepopuleran objek } \\
\text { wisata dengan } \\
\text { batiknya } \\
\end{array}$ & Ordinal \\
\hline
\end{tabular}




\begin{tabular}{|c|c|c|c|c|}
\hline $\begin{array}{c}\text { Variabel/ Sub } \\
\text { Variabel }\end{array}$ & Konsep Variabel & Indikator & Ukuran & Skala \\
\hline \multirow[t]{3}{*}{1} & 2 & 3 & 4 & 5 \\
\hline & & $\begin{array}{l}\text { Kesesuaian jam } \\
\text { buka showroom } \\
\text { atau toko }\end{array}$ & $\begin{array}{ll}\text { - } & \text { Tingkat } \\
\text { Kesesuaian jam } \\
\text { buka showroom } \\
\text { atau toko }\end{array}$ & Ordinal \\
\hline & & $\begin{array}{ll}\text { Kemudahan } \\
\text { menjangkau } \\
\text { lokasi kawasan }\end{array}$ & $\begin{array}{ll}\text { - } & \text { Tingkat } \\
\text { kemudahan akses } \\
\text { menuju kawasan }\end{array}$ & Ordinal \\
\hline \multirow[t]{4}{*}{$\begin{array}{l}\text { Merchandising } \\
\text { (X.3) }\end{array}$} & & 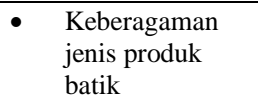 & $\begin{array}{ll} & \text { Tingkat } \\
\text { keberagaman jenis } \\
\text { produk batik }\end{array}$ & Ordinal \\
\hline & & $\begin{array}{l}\text { Keberagaman } \\
\text { souvenir atau } \\
\text { kerajinan } \\
\text { tangan yang } \\
\text { diberikan }\end{array}$ & $\begin{array}{l}\text { Tingkat } \\
\text { keberagaman } \\
\text { souvenir atau } \\
\text { kerajinan tangan } \\
\text { yang diberikan }\end{array}$ & Ordinal \\
\hline & & $\begin{array}{l}\text { Kemenarikan } \\
\text { souvenir atau } \\
\text { kerajinan tangan } \\
\text { yang diberikan }\end{array}$ & $\begin{array}{l}\text { Tingkat } \\
\text { kemenarikan } \\
\text { souvenir atau } \\
\text { kerajinan tangan } \\
\text { yang diberikan }\end{array}$ & Ordinal \\
\hline & & 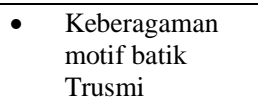 & $\begin{array}{ll} & \text { Tingkat } \\
\text { keberagaman } \\
\text { motif batik Trusmi }\end{array}$ & Ordinal \\
\hline \multirow[t]{5}{*}{ Keaslian (X.4) } & & $\begin{array}{ll} & \text { Product } \\
& \text { Uniqueness }\end{array}$ & $\begin{array}{ll} & \text { Tingkat keunikan } \\
& \text { motif batik Trusmi }\end{array}$ & Ordinal \\
\hline & & & $\begin{array}{ll}\text { - } & \text { Tingka. Keunikan } \\
& \text { souvenir }\end{array}$ & Ordinal \\
\hline & & - $\quad$ Aesthetics & $\begin{array}{l}\text { Daya tarik visual } \\
\text { batik/souvenir }\end{array}$ & Ordinal \\
\hline & & - Workmanship & $\begin{array}{l}\text { - } \quad \begin{array}{l}\text { Tingkat kualitas } \\
\text { batik Trusmi }\end{array}\end{array}$ & Ordinal \\
\hline & & & $\begin{array}{l}\text { - Tingkat kualitas } \\
\text { souvenir }\end{array}$ & Ordinal \\
\hline \multirow[t]{5}{*}{$\begin{array}{l}\text { Staff Service } \\
\text { Quality (X.5) }\end{array}$} & & $\begin{array}{ll} & \text { Pengetahuan } \\
\text { karyawan } \\
\text { terhadap produk }\end{array}$ & $\begin{array}{ll} & \text { Tingkat } \\
\text { pengetahuan } \\
\text { karyawan } \\
\text { terhadap produk }\end{array}$ & Ordinal \\
\hline & & $\begin{array}{l}\text { Kemampuan } \\
\text { karyawan dalam } \\
\text { berbahasa }\end{array}$ & $\begin{array}{ll} & \text { Tingkat } \\
\text { kemampuan } \\
\text { karyawan dalam } \\
\text { berbahasa }\end{array}$ & Ordinal \\
\hline & & $\begin{array}{ll}\text { Kesopanan } \\
\text { sikap yang } \\
\text { diperlihatkan } \\
\text { karyawan }\end{array}$ & $\begin{array}{l}\text { - } \text { Tingkat } \\
\text { kesopanan sikap } \\
\text { yang diperlihatkan } \\
\text { karyawan }\end{array}$ & Ordinal \\
\hline & & & $\begin{array}{l}\text { - } \\
\text { kingkat } \\
\text { keramahan } \\
\text { karyawan }\end{array}$ & Ordinal \\
\hline & & & $\begin{array}{ll}- & \text { Daya tanggap } \\
\text { karyawan }\end{array}$ & Ordinal \\
\hline
\end{tabular}




\begin{tabular}{|c|c|c|c|c|}
\hline $\begin{array}{c}\text { Variabel/Sub } \\
\text { Variabel }\end{array}$ & Konsep Variabel & Indikator & Ukuran & Skala \\
\hline 1 & 2 & 3 & 4 & 5 \\
\hline \multirow[t]{5}{*}{$\begin{array}{l}\text { Brand Image } \\
(\mathrm{Y})\end{array}$} & $\begin{array}{l}\text { Brand image menjelaskan faktor- } \\
\text { faktor luar daripada produk atau jasa, } \\
\text { termasuk bagaimana brand image } \\
\text { menemukan jalannya sendiri untuk } \\
\text { kebutuhan fisik dan sosial. (Kotler } \\
\text { dan Keller, 2009:285) }\end{array}$ & & & \\
\hline & & \multirow[t]{4}{*}{ Strength } & $\begin{array}{l}\text { - } \\
\text { ingakat kekuatan } \\
\text { ingatasatawan } \\
\text { terhadap kawasan } \\
\text { objek wisata } \\
\text { belanja Batik } \\
\text { Trusmi }\end{array}$ & Ordinal \\
\hline & & & $\begin{array}{ll} & \text { Tingkat kekuatan } \\
\text { ingatan wisatawan } \\
\text { terhadap motif } \\
\text { batik Trusmi }\end{array}$ & Ordinal \\
\hline & & & $\begin{array}{ll}\text { - Tingkat kekuatan } \\
\text { informasi yang } \\
\text { disampaikan } \\
\text { kepada wisatawan }\end{array}$ & Ordinal \\
\hline & & & $\begin{array}{l}\text { Tingkat kekuatan } \\
\text { pemahaman } \\
\text { informasi yang } \\
\text { disampaikan } \\
\text { kepada wisatawan }\end{array}$ & Ordinal \\
\hline & & Favorability & $\begin{array}{ll}\text { - } & \text { Tingkat } \\
\text { kemenarikan } \\
\text { merek yang } \\
\text { ditawarkan batik } \\
\text { Trusmi }\end{array}$ & Ordinal \\
\hline & & & $\begin{array}{ll} & \text { Tingkat } \\
\text { keungguan batik } \\
\text { Trusmi } \\
\text { dibandingkan } \\
\text { dengan batik lain }\end{array}$ & Ordinal \\
\hline & & & $\begin{array}{ll} & \text { Tingkat } \\
\text { kemenarikan } \\
\text { informasi yang } \\
\text { diberikan kepada } \\
\text { wisatawan }\end{array}$ & Ordinal \\
\hline & & \multirow[t]{3}{*}{ Uniqueness } & $\begin{array}{ll}\text { - } & \text { Tingkat keunikan } \\
\text { motif batik yang } \\
\text { ditawarkan }\end{array}$ & Ordinal \\
\hline & & & $\begin{array}{l}\text { - Tingkat keunikan } \\
\text { bahan dasar batik } \\
\text { yang ditawarkan }\end{array}$ & Ordinal \\
\hline & & & $\begin{array}{ll}\text { - } & \text { Tingkat keunikan } \\
\text { arsitektur } \\
\text { showroom batik }\end{array}$ & Ordinal \\
\hline
\end{tabular}

\subsubsection{Metode Penarikan Sampel}

Sampel dalam penelitian ini yaitu pengunjung Kawasan Objek Wisata Belanja Batik Trusmi. Jumlah sampel yang diambil dalam penelitian ini sebesar 100 sampel dari jumlah populasi wisatawan nusantara pada tahun 2010 sebanyak 165.386 dengan menggunakan rumus Slovin. 


\subsubsection{Prosedur Pengumpulan Data}

Pengumpulan data yang dilakukan penulis menggunakan teknik sebagai berikut.:

1. Wawancara

2. Observasi

3. Studi literatur

4. Angket/kuesioner

\subsubsection{Pengujian Hipotesis}

Teknik untuk menguji data yang digunakan dalam penelitian kuantitatif ini adalah metode analisis verifikatif. maka dilakukan analisis jalur (path analysis).Dalam Hal ini jalur yang digunakan untuk menentukan besarnya variabel indipenden $\left(X_{1}, X_{2} . X_{3}, X_{4} \cdot X_{5}\right)$ dimana hargasebagai $\mathrm{X}_{1}$, karakteristik destinasi $\mathrm{X}_{2}$, merchandising $\mathrm{X}_{3}$, keaslian $\mathrm{X}_{4}$, dan staff service quality $\mathrm{X}_{5}$ terhadap $\mathrm{Y}$ baik secara langsung maupun tidak langsung. Pengujian hipotesis dilakukan dengan menggambar struktur hipotesis

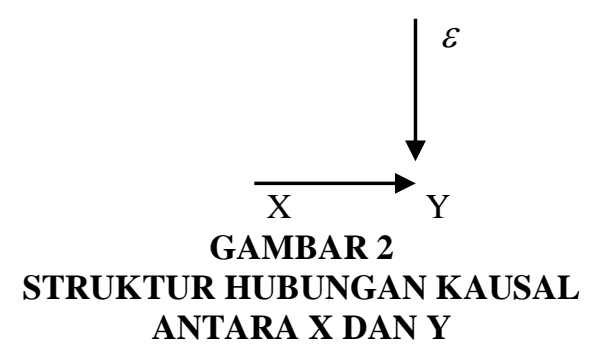

Struktur Hubungan antara $\mathrm{X}$ dan $\mathrm{Y}$ diuji melalui analisis jalur dengan hipotesis yang berbunyi terdapat pengaruh yang signifikan antara shopping experience yang terdiri dari harga $\left(\mathrm{X}_{1}\right)$, karakteristik destinasi $\left(\mathrm{X}_{2}\right)$, merchandising $\left(\mathrm{X}_{3}\right)$, keaslian $\left(\mathrm{X}_{4}\right)$ dan staff service quality $\left(\mathrm{X}_{5}\right)$ dan brand image (Y). Selanjutnya struktur hubungan diatas diterjemahkan kedalam hipotesis yang menyatakan pengaruh variabel bebas yang dominan terhadap variabel terikat. Untuk lebih jelas dapat dilihat pada Gambar 3 Berikut.

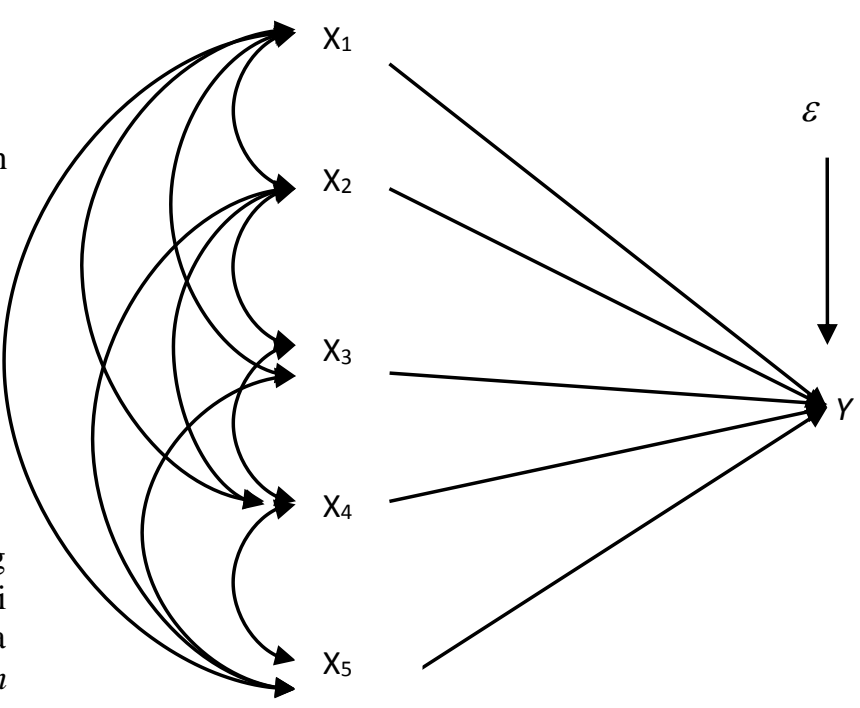

GAMBAR 3

DIAGRAN JALUR STRUKTUR HIPOTESIS UTAMA

\begin{tabular}{lll}
\hline IV. & HASIL PENELITIAN & DAN \\
& PEMBAHASAN & \\
4.1 & $\begin{array}{l}\text { Tanggapan Responden } \\
\text { Promotion Mix } \\
\text { Tanggapan responden dari kelima }\end{array}$
\end{tabular}
shopping experience yaitu harga, karakteristik destinasi, merchandising, keaslian dan staff service quality. Keaslian batik Trusmi memiliki skor tertinggi yaitu 2008 atau sebesar $24,80 \%$ untuk mempengaruhi wisatawan datang ke Kawasan Objek Wisata Belanja batik Trusmi. Keaslian batik Trusmi dapat dilihat dari cara pengerjaannya, nilai budaya dan sejarahnya, jaminan keasliannya, keunikan produknya dan fungsi serta manfaat produknya. Menurut Darren J. Timothy (2005:78) menyebutkan bahwa keunikan produk merupakan komponen penting dalam membuat sesuatu yang otentik di mata banyak wisatawan dan menarik persepsi wisatawan.

\subsection{Tanggapan Responden Terhadap Keputusan Berkunjung}

Tanggapan responden dari ketiga brand image yaitu strength, favourability dan uniqueness yang tertinggi adalah strength yaitu dengan skor 1351 atau sebesar 40,83\%. Hal ini dikarenakan kekuatan ingatan wisatawan mengenai Kawasan Objek Wisata Belanja Batik Trusmi sangat kuat karena kawasan Trusmi merupakan andalan dan satu-satunya kawasan objek wisata batik di Kabupaten Cirebon. Sedangkan tanggapan responden yang terendah adalah favourability dengan skor 817 atau sebesar $24,70 \%$. Hal 
tersebut dikarenakan kurang beragamnya motif batik Trusmi, karena batik Trusmi masih melestarikan motif-motif yang telah ada dan kurang diperkenalkannya motif baru sehingga wisatawan merasa kurang tertarik dengan motif yang baru.

\subsection{Pengaruh Promotion Mix Terhadap Keputusan Berkunjung}

Pengujian hipotesis untuk menguji besarnya pengaruh shopping experience yang terdiri dari harga(X1.1), karakteristik destinasi (X1.2), merchandising (X1.3), kaeslian (X1.4), dan staff service quality (X1.5) terhadap brand image (Y). Hasil korelasi antara shopping experience dengan brand image dalam Tabel 3 berikut ini:

TABEL 3

MATRIKS KORELASI ANTARA SUB VARIABEL SHOPPING EXPERIENCE DENGAN BRAND IMAGE

\begin{tabular}{|c|c|c|c|c|c|c|}
\hline & $\mathbf{Y}$ & $\mathbf{X 1 . 1}$ & $\mathbf{X 1 . 2}$ & $\mathbf{X 1 . 3}$ & $\mathbf{X 1 . 4}$ & $\mathbf{X 1 . 5}$ \\
\hline $\mathbf{Y}$ & 1 & 0,414 & 0,337 & 0,201 & 0,773 & 0,003 \\
\hline $\mathbf{X 1 . 1}$ & 0,414 & 1 & 0,638 & 0,098 & 0,217 & 0,025 \\
\hline $\mathbf{X 1 . 2}$ & 0,337 & 0,638 & 1 & 0,009 & 0,322 & 0,034 \\
\hline $\mathbf{X 1 . 3}$ & - & - & & & & - \\
\hline $\mathbf{X 1 . 4}$ & 0,201 & 0,098 & 0,009 & 1 & 0,031 & 0,022 \\
\hline $\mathbf{X 1 . 5}$ & - & - & - & - & - & - \\
\hline
\end{tabular}

Sumber: Hasil Pengolahan Data, 2011

Berdasarkan matriks korelasi antara sub variabel shopping experience terhadap brand image diperoleh hasil korelasi secara berurutan yaitu, harga $(0,414)$, karakteristik destinasi(0,337), merchandising (0,201), keaslian $(0,773)$, dan staff service quality
(0,003). Berikut disajikan pengujian koefisien jalur setiap sub variabel shopping experience dan kontribusi secara langsung maupun tidak langsung setiap sub variabel shopping experience terhadap brand image pada tabel berikut.

TABEL 4

HASIL PENGUJIAN KOEFISIEN JALUR SERTA PENGARUH LANGSUNG DAN TIDAK LANGSUNG VARIABEL SHOPPING EXPERIENCE TERHADAP BRAND

IMAGE

\begin{tabular}{|c|c|c|c|c|c|c|c|c|c|c|}
\hline \multirow[b]{2}{*}{$\mathrm{X}$} & \multirow{2}{*}{$\begin{array}{c}\text { Pengaruh } \\
\text { Langsung } \\
\text { terhadap } \\
\text { Y }\end{array}$} & \multicolumn{5}{|c|}{ Pengaruh Tidak Langsung Melalui } & \multirow[b]{2}{*}{$\mathrm{R}^{2}{ }_{\mathrm{YX} 1.1, \ldots . . . \mathrm{YX} 1.5}$} & \multirow[b]{2}{*}{$t_{\text {hitung }}$} & \multirow[b]{2}{*}{ Sig. } & \multirow[b]{2}{*}{ Keputusan } \\
\hline & & $\mathrm{X} 1.1$ & $\mathrm{X} 1.2$ & $\mathrm{X} 1.3$ & $\mathrm{X} 1.4$ & $\mathrm{X} 1.5$ & & & & \\
\hline $\mathrm{X} 1.1$ & 0,082 & - & $-0,057$ & 0,0045 & $-0,059$ & $-0,093$ & 0,1185 & 3,958 & 0,000 & Ho ditolak \\
\hline $\mathrm{X} 1.2$ & 0,007 & $-0,057$ & - & $-0,004$ & 0,053 & 0,058 & $-0,0261$ & $-1,135$ & 0,259 & Ho diterima \\
\hline $\mathrm{X} 1.3$ & 0,037 & $\begin{array}{c}0,004 \\
5\end{array}$ & $-0,0035$ & - & $-0,0039$ & $-0,0033$ & 0,0384 & $-3,468$ & 0,001 & Ho ditolak \\
\hline $\mathrm{X} 1.4$ & 0,567 & 0,059 & 0,053 & $-0,004$ & - & 0,037 & 0,583 & 12,787 & 0,000 & Ho ditolak \\
\hline $\mathrm{X} 1.5$ & 0,006 & $-0,023$ & 0,058 & $-0,003$ & 0,037 & - & 0,001 & 1,408 & 0,162 & Ho diterima \\
\hline $\mathrm{R}^{2}$ & & & & & & & 0,7148 & & & \\
\hline
\end{tabular}

Sumber: Hasil Pengolahan Data, 2010

Pengujian hipotesis melalui uji signifikansi dan uji-t menghasilkan penolakan terhadap Ho untuk harga, merchandising, dan keaslian, karena nilai signifikansi lebih kecil dibandingkan dengan 0,1 . Hal tersebut berarti bahwa terdapat pengaruh yang signifikan antara harga, merchandising dan keaslian terhadap brand image. Sedangkan Ho diterima untuk karakteristik destinasi dan staff service quality yang berarti bahwa tidak terdapat pengaruh yang signifikan antara karakteristik 
destinasi dan staff service quality terhadap brand image. Berdasarkan hasil perhitungan di atas dapat diketahui bahwa pengaruh shopping experienceterhadap brand image adalah sebesar 0,7148 sedangkan koefisien jalur variabel lain di luar variabel shopping experience yaitu harga, merchandising, dan keaslian ditentukan melalui:

$$
\begin{aligned}
& P_{Z \varepsilon}=\sqrt{1-R_{Y(X 1.1, \ldots X 1.5)}^{2}} \\
& =\sqrt{1-0,714} 8 \\
& =0,2852
\end{aligned}
$$

Hal tersebut berarti bahwa X1.1 sampai X1.5 bersama-sama mempengaruhi brand image sebesar $71,48 \%$ dan sisanya sebesar $(0,2852)^{2}=0,0813 \times 100 \%=8,13 \%$ dipengaruhi faktor lain yang tidak masuk ke dalam penelitian ini seperti promotion mix, pengembangan produk, strategi penetapan harga, dan program pemasaran lainnya di Kawasan Objek Wisata Belanja Batik Trusmi.

Berdasarkan hasil pengujian hipotesis tersebut, terdapat dua sub variabel shopping experience yang tidak signifikan yaitu karakteristik destinasi dan staff service quality. Oleh karena itu, sub variabel yang tidak signifikan tersebut dihilangkan dalam penghitungan selanjutnya. Metode ini dalam kajian path analysis disebut dengan model trimming yaitu "Deleting one path at a time until a significant chi-square difference indicates trimming has gone too far. A nonsignificant chi-square difference means the researcher should choose the more parsimonious model" (Garson, 2009). Dalam hal ini model trimming dilakukan guna menghindari hasil yang tidak signifikan terhadap sub variabel shopping experience yang disebabkan oleh dua sub variabel tersebut sehingga data yang diperoleh diolah kembali. Pengujian hipotesis selanjutnya hanya terdiri dari tiga sub variabel yaitu harga, merchandising, dan keaslian.

Hasil korelasi antara shopping experience yang terdiri dari harga (X1.1), merchandising (X1.2), dan keaslian (X1.3), terhadap brand image dengan menggunakan model trimming disajikan dalam Tabel 5 berikut ini:

TABEL 5

MATRIKS KORELASI ANTARA SUB VARIABEL SHOPPING EXPERIENCE DENGAN BRAND IMAGE MENGGUNAKAN MODEL TRIMMING

\begin{tabular}{|c|c|c|c|c|}
\hline & Y & X1.1 & X1.3 & X1.4 \\
\hline Y & 1 & 0,414 & 0,201 & 0,773 \\
\hline X1.1 & 0,414 & 1 & 0,098 & 0,217 \\
\hline X1.3 & - & - & & \\
& 0,201 & 0,098 & 1 & 0,031 \\
\hline X1.4 & 0,773 & 0,217 & 0,031 & 1 \\
\hline
\end{tabular}

Sumber: Hasil Pengolahan Data, 2010

Berdasarkan hasil matriks korelasi antara sub variabel shopping experience yaitu harga, merchandising, dan keaslian terhadap brand image diperoleh hasil korelasi secara berurutan yaitu harga $(0,414)$, merchandising $(-0,201)$, dan keaslian $(0,773)$.

Keaslian tetap memperoleh korelasi terbesar, dengan nilai korelasi $(0,773)$. Hal tersebut dikarenakan keaslian Kawasan Objek Wisata Belanja Batik Trusmiseperti keunikan motif batik, kualitas batik, daya tarik visual batik, kualitas keunikan souvenir dan kualitas souvenir, mampu menarik wisatawan untuk datang berkunjung dan berbelanja. Wisatawan akan lebih tertarik dengan keaslian produk batik Trusmi sehingga wisatawan akan datang berkunjung dan berbelanja ke Kawasan Objek Wisata Belanja Batik Trusmi.

Berikut disajikan pengujian koefisien jalur setiap sub variabel shopping experience dan kontribusi secara langsung maupun tidak langsung setiap sub variabel shopping experience terhadap brand image menggunakan model trimming pada Tabel 6 sebagai berikut: 
TABEL 6

HASIL PENGUJIAN KOEFISIEN JALUR SERTA PENGARUH LANGSUNG DAN TIDAK LANGSUNG VARIABEL SHOPPING EXPERIENCE TERHADAP BRAND IMAGE MENGGUNAKAN MODEL TRIMMING

\begin{tabular}{|c|c|c|c|c|c|c|c|c|}
\hline \multirow{2}{*}{$\mathrm{X}$} & \multirow{2}{*}{$\begin{array}{c}\text { Pengaruh } \\
\text { Langsung } \\
\text { terhadap } \\
\text { Y }\end{array}$} & \multicolumn{3}{|c|}{$\begin{array}{c}\text { Pengaruh Tidak Langsung } \\
\text { Melalui }\end{array}$} & \multirow{2}{*}{$\mathrm{R}^{2} \mathrm{YX} 1.1, \ldots . . \mathrm{YX} 1}$. & \multirow{2}{*}{$t_{\text {hitung }}$} & \multirow{2}{*}{ Sig. } & \multirow{2}{*}{ Keputusan } \\
\hline & & $\mathrm{X} 1.1$ & $\mathrm{X} 1.3$ & $\mathrm{X} 1.4$ & & & & \\
\hline $\mathrm{X} 1.1$ & 0,414 & - & $-0,098$ & 0,217 & 0,189 & 4,110 & 0,000 & Ho ditolak \\
\hline $\mathrm{X} 1.3$ & $-0,201$ & $-0,098$ & - & 0,031 & 0,015 & $-3,577$ & 0,001 & Ho ditolak \\
\hline X1.4 & 0,773 & 0,217 & 0,031 & - & 0,574 & 12,731 & 0,000 & Ho ditolak \\
\hline $\mathrm{R}^{2}$ & & & & & 0,778 & & & \\
\hline
\end{tabular}

Sumber: Hasil Pengolahan Data, 2010

Berdasarkan hasil perhitungan di atas setalah dilakukan proses trimming dapat diketahui bahwa pengaruh shopping experience terhadap brand image adalah sebesar 0,778 sedangkan koefisien jalur variabel lain diluar shopping experience yaitu harga, merchandising, dan keaslian ditentukan melalui.

$$
\begin{aligned}
& P_{Z \varepsilon}=\sqrt{1-R_{Y(X 1.1, \ldots X 1.5)}^{2}} \\
& =\sqrt{1-0,778} \\
& =0,222
\end{aligned}
$$

Hal tersebut berarti bahwa X1.1, X1.3 dan X1.4 bersama-sama mempengaruhi brand image sebesar $77,8 \%$ dan sisanya sebesar $(0,222)^{2}=0,0492 \times 100 \%=4,92 \%$ dipengaruhi faktor lain yang tidak masuk ke dalam penelitian ini.

\section{KESIMPULAN}

Berdasarkan hasil penelitian secara deskriptif dan verifikatif dapat disimpulkan sebagai berikut:

1. Pelaksanaan shopping experience di Kawasan Objek Wisata Belanja Batik Trusmi terdiri dari harga, karakteristik destinasi, merchandising, keaslian, dan staff service quality memiliki penilaian yang baik dari wisatawan. Sub variabel yang mendapat penilaian skor rata-rata tertinggi adalah keaslian melalui keunikan motif batik dan souvenir, kualitas batik dan souvenir, dan daya tarik visual batik dan souvenir dengan total skor 2008 atau sebesar 24,80\% sedangkan yang mendapatkan penilaian terendah adalah harga dengan total skor 1130 atau sebesar $13,96 \%$.

2. Penilaian wisatawan mengenai brand image yang terdiri dari strength, favourability dan uniqueness di
Kawasan Objek Wisata Belanja Batik Trusmi mendapatkan penilaian yang baik dari wisatawan. Indikator yang mendapat penilaian skor rata-rata tertinggi adalah strength melalui kekuatan wisatawan mengenai Kawasan Objek Wisata Belanja Batik Trusmi dengan total skor 1351 atau sebesar $40,83 \%$ sedangkan yang mendapatkan penilaian terendah adalah favourability dengan total skor 817 atau sebesar $24,70 \%$.

3. Berdasarkan hasil pengujian hipotesis yang telah dilakukan, bahwa terdapat pengaruh yang positif antara shopping experience terhadap brand image di Kawasan Objek Wisata Belanja Batik Trusmi. Pernyataan tersebut dapat dibuktikan pada hasil pengujian hipotesis yang telah dilakukan dimana secara keseluruhan nilai $t_{\text {hitung }}$ yang diperoleh melalui analisis path lebih besar dibandingkan dengan $\mathrm{t}_{\text {tabel }}$, artinya semakin baik shopping experience yang dilakukan maka akan semakin mempengaruhi brand image di Kawasan Objek Wisata Belanja Batik Trusmi

\section{DAFTAR PUSTAKA}

Asep Hermawan, (2006), Penelitian Bisnis Paradigma Kuantitatif, Jakarta, Grasindo.

Atila Yuksel, School of Tourism and Hotel Management, Adnan Menderes University, Candan Tarhan Bulvari, Turkey, 2005. Tourist Shopping Habitat: Effect on Emotions, Shopping Value and Behaviors.

David R. Bell and James M. Lattin, Andersson School of Management, University of California-Los Angeles, 2008. Shopping Behavior 
and Consumer Preference for Store Price Format: Why "Large Basket" Shopper Prefer EDLP.

Fandy Tjiptono Gregorius Chandra dan Dedi Adriana (2008). Pemasaran Strategik. Yogyakarta.

Garson, David. 2009. Diakses melalui http://faculty.chass.nscu.edu/garson / /PA765/Structur.htm pada tanggal 2 Maret 2010.

Harun Al Rasyid, (1994), Teknik Penarikan Sampel dan Penyusunan Skala, Bandung, Program Studi Ilmu Sosial Bidang Kajian Utama Sosiologi Antropologi Program Pasca Sarjana UNPAD.

Husein Umar, (2008), Metode Penelitian Untuk Skripsi dan Tesis Bisnis, Edisi Kedua, Jakarta, Rajawali Pers.

J.R. Short, L.M. Benton, W.B. Luce and J.Walton, Department of Geography, Syracuse University, Syrause, 2003. Reconstructing The Image of an Industrial City.

Jansson, Johan and Dominic Power, 2006, Image of The City.

Kotler, Bowen \& Maken, 2011, Marketing for Hospitality and Tourism, New Jersey, Upper Saddle River.

Kevin, Keller, 2007, Strategy Business Mamagement, Jakarta, Gramedia Pustaka Utama.

Kotler, Philip and Keller Kevin Lane, 2009, Marketing Management, (thirdteen ed), New Jersey, Prentice Hall.

Marie Elka Simatupang, (2008), Pengembangan Ekonomi Kreatif Indonesia Edisi 2, Jakarta, Departemen Perdagangan Indonesia.

Nyoman S.Pendit, (2003), Ilmu Pariwisata: Sebuah Pengantar Perdana, Jakarta, PT. Percetakan Penebar Swadaya.

I Gde Pitana dan I Ketut Surya Diarta, (2009), Pengantar Ilmu Pariwisata, Yogyakarta, Andi Offset.

I Gde Pitana dan Gayatri, (2005), Sosiologi Pariwisata, Yogyakarta, Andi Offset.

Raluca C. Dridea,. Sztruten Gina, 2009, The Impact of Shopping Tourism on The
Future of Leisure Services. Romanian American University.

Sugiyono, (2008), Metodologi Penelitian Bisnis, Bandung, Alfabeta.

, (2010), Metode penelitian kuantitatif kualitatif dan $R \& D$, Bandung, Alfabeta. , (2010), Statistika Untuk Penelitian, Bandung, Alfabeta.

Suharsimi Arikunto, (2006), Prosedur Penelitian: Suatu Pendekatam Praktek (Edisi Revisi 5), Jakarta, PT. Rineka Cipta

Ekonomi USU, Medan, (2008). Destination Brand: Membangun Keunggulan Bersaing Dearah.

Timothy, Darren J., 2005, Shopping Tourism, Retailing and Leisure. Channel View: Clevendon, UK.

Tosun C. dan Darren J. Timothy, 2007, Tourist Shopping Experience and Satisfaction. Wiley InterScience.

Ulber Silalahi, (2009), Metode Penelitian Sosial, Bandung, Refika Aditama.

Uma Sekaran, (2006), Metode Penelitian Untuk Bisnis, Jakarta, Salemba Empat.

Wanjiru, Evalyne, 2005, Branding African Country: A Prospect for The Future.

Website:

www.detik.com diakses pada tanggal 2 April 2010

www.bennythegreat.wordpress.com diakses pada tanggal 2 April 2010

www.kartikablog.com diakses pada tanggal 2 April 2010

www.noem3d.wordpress.com diakses pada tanggal 2 April 2010

www.rinafebrianiblog.com diakses pada tanggal 17 Februari 2010

www.rumahaulia.com diakses pada tanggal 5 Juli 2010

www.thearoengbinangtravelog.com diakses pada tanggal 2 April 2010 
